\title{
Soil Fertility in Africa Is at Stake
}

\author{
Eric M. A. Smaling \\ Research Institute for Agrobiology and Soil Fertility \\ Wageningen, the Netherlands
}

Stephen M. Nandwa

Kenya Agricultural Research Institute

Nairobi, Kenya

Bert H. Janssen

Wageningen Agricultural University

Wageningen, the Netherlands

\begin{abstract}
Soil fertility in Africa is under pressure as an increasing number of farmers attempt to make a living based on what the land can offer to growing plants. Studies in Africa from about 1989 have focused on different spatial scales, i.e., subcontinental, subnational, and farm. This chapter reviews the results obtained at these three levels and compares methodologies and implications. For $\mathrm{N}$, annual depletion was recorded at all levels at rates of 22 $\mathrm{kg} \mathrm{ha}^{-1}$ (sub-Saharan Africa), $112 \mathrm{~kg} \mathrm{ha}^{-1}$ (Kisii District, Kenya), and $71 \mathrm{~kg} \mathrm{ha}^{-1}$ (average for 26 farms in Kisii, Kakamega, and Embu Districts). If the soil nutrient balance is to become a suitable land quality indicator for wider use as a policy instrument, increased sophistication is required, including data on soil nutrient stocks and availability. The advantage of the nutrient balance approach over traditional rate-response research on fertilizers is that it includes all possible nutrient flows at the spatial scales discussed. A drawback, however, is the lack of hard data on flows that are difficult to measure (leaching, gaseous losses, and erosion), and the fact that the balance comprises several inputs minus the sum of several outputs. Nonetheless, the message comes out clearly that improved soil nutrient management is crucial for maintaining and improving soil productivity in Africa.
\end{abstract}

Soil fertility is not a static feature. On the contrary, it changes constantly and its direction (accumulation or depletion) is determined by the interplay between physical, chemical, biological, and anthropogenic processes. This dynamism also is reflected in terminology such as nutrient cycles, budgets, or balances, referring to inputs and outputs in natural ecosystems and managed agroecosystems, to which nutrients are added and from which nutrients are removed. As the world

Copyright 1997 American Society of Agronomy and Soil Science Society of America, $677 \mathrm{~S}$. Segoe Rd., Madison, WI 53711, USA. Replenishing Soil Fertility in Africa. SSSA Special Publication no. 51 . 
population keeps growing, balanced ecosystems are on the decrease and nutrient ledgers all over the world have become increasingly imbalanced. Great nutrient surpluses and subsequent undesirable emissions to the environment now occur in many farming systems in temperate regions, and increasing soil-nutrient depletion and crop yield declines are reported in the tropics, particularly in rainfed subSaharan Africa (hereafter referred to as Africa; Pieri, 1989; Stoorvogel \& Smaling, 1990; Van der Pol, 1992). In rural appraisals, an increasing number of African farmers indeed mention soil fertility decline as a major constraint to farming.

The yield-increasing effect of mineral fertilizers has long been the main nutrient management technology researched, amongst others, by the numerous though poorly documented rate-response trials of the FAO Fertilizer Programme. Presently, however, land-use planning approaches are aimed at integrated nutrient management (INM), perceived here as the best combination of available nutrient management technologies, i.e., those that suit local biophysical conditions and are economically attractive and socially relevant (Smaling et al., 1996). FAO has also adopted this philosophy and now nuns an Integrated Plant Nutrition Programme in different parts of the tropics. Integrated nutrient management technologies can be nutrient saving, such as in controlling erosion and recycling crop residues, manure, and other biomass, or nutrient adding, such as in applying mineral fertilizers and importing feedstuffs for livestock. Some practices strive at both, such as improved fallowing and agroforestry. As each agroecological zone has its potentials and limitations, the number of relevant INM options is site specific. In the eastern African highlands, for example, with reliable rainfall and deep, relatively fertile soils, more options are available to safeguard productivity than in semiarid West Africa, with less and erratic rainfall and sandy, often shallow soils. Of late, the nutrient balance and INM have been adopted by the World Bank as key to the debate on sustainable agricultural systems in the tropics. As a consequence, work is under way to turn the nutrient balance into a land quality indicator (Pieri et al., 1995).

Nutrient balances apply to different spatial scales. To visualize this, one should build an imaginary fence around the system of interest. For the farm system, for example, this fence surrounds the entire farm holding. The floor runs just below the root zone of plant species that grow in the particular farming systems, whereas the roof stretches over the top of the tallest species. Now one can determine whether a nutrient flow is really an input or an output, i.e., crossing this fence, or whether one deals with an internal flow inside the fence. Concentrates purchased to feed stalled cattle, for example, are nutrient inputs to the farm, but roughage such as napier grass (Pennisetum purpureum Schumach.) or silage maize (Zea mays $\mathrm{L}$.) grown within the farm is no input at this level. It is, however, an output for the plot where these plants were grown, and an input to the stable, which are both compartments of the farm. Similarly, soil that leaves the farm through water erosion represents a nutrient output, but eroded soil from upper slopes may enter the same farm and become an input. Eroded soil reaching rivers may end up in the ocean and is also then an output at the country scale. Another percentage may, however, be deposited as sediment in flood plains in the lower parts of the river basin. This is the case in large parts of agricultural China, where 
soils in the plains remain productive by virtue of erosion in the mountains. At the level of the soil solution, the nutrient balance in fact represents plant-nutrient availability. Any applied $P$ fertilizer is an input to the farm and the soil, but a large part may be strongly sorbed by sesquioxides or precipitated, and as such it is no immediate input to the soil solution. In other words, nutrient availability reflects a nutrient balance at soil-solution level, modified by the process groups mineralization-immobilization (highly important for $\mathrm{N}, \mathrm{S}$, and often $\mathrm{P}$ ), sorption-desorption (highly important for $\mathrm{P}$ and cations) and weathering-precipitation (highly important for micronutrients and $\mathrm{P}$ ).

In this chapter, results are summarized from earlier and ongoing nutrient balance studies in Africa at subcontinental, subnational, farm, and field levels. Differences in interpretation among these studies are discussed and future avenues for nutrient-balance research given.

\section{CALCULATING NUTRIENT BALANCE AT DIFFERENT SPATIAL SCALES}

\section{Subcontinental Scale}

In the late 1980 s, FAO replaced its fertilizer-driven philosophy by an INM approach, which triggered a debate on high versus low external input farming. In this context, FAO commissioned a study on nutrient balances in agricultural systems in Africa, with the aim of creating awareness on not just the state of soil fertility in the subcontinent but also its dynamics. The nutrient balance study for 38 African countries (Stoorvogel \& Smaling, 1990; Stoorvogel et al., 1993) involved partitioning the continent into rainfed cultivated, irrigated, and fallow land, for which FAO provided hectarages and yields. Rainfed land was further divided on the basis of the length of the growing period and the soil map of Africa, at a scale of 1:5000000 (FAO/UNESCO, 1977). The basic spatial unit was the land-use system, for which five nutrient inputs and five nutrient outputs were calculated or estimated (Table 2-1). For this exercise, many country statistics, maps, reports, and literature were scrutinized. A detailed account of the information gathered and interpreted is annexed to the main document by Stoorvogel and Smaling (1990).

The amount of data available to calculate the five inputs (IN 1 to 5) and the five outputs (OUT 1 to 5; Table 2-1) varied largely between and within countries. As a consequence, much available detail had to be dropped and discrete ratings developed for variables that normally represent a continuum. Also, average values were used for properties that showed wide ranges, such as crop-nutrient contents. Quantitative information on atmospheric deposition, leaching, and gaseous losses was very scarce. Instead of going by educated guesses, transfer functions were built (Bouma \& Van Lanen, 1987; Wagenet et al., 1991). These are regression equations, in which the nutrient flow is explained by parameters that are easy to measure. For leaching, for example, the equations represent the best fit for a series of point data on leaching, which were accompanied by such building 
Table 2 -1. Nutrient inputs and outputs calculated in continental and district studies.

\begin{tabular}{cl}
\hline Nutrient inputs & Mineral fertilizers \\
IN 1 & Organic inputs (manure, feeds, waste) \\
IN 2 & Atmospheric deposition in rain and dust \\
IN 3 & Biological nitrogen fixation \\
NN 4 & Sedimentation by irrigation and natural flooding \\
IN 5 & \\
Nutrient outputs & Harvested products \\
OUT 1 & Crop residue removal \\
OUT 2 & Solute leaching \\
OUT 3 & Gaseous losses \\
OUT 4 & Runoff and erosion \\
OUT 5 & \\
\hline
\end{tabular}

blocks as rainfall, soil fertility class, and use of fertilizer and manure. Soil fertility classes were merely rated low (1), moderate (2), and high (3) on the basis of soil taxonomy (sub)orders. Mollisols, for example, were ranked 3, whereas Psamments were ranked 1. For erosion, quantitative information on soil loss was amply available, but its translation into nutrient losses was seldom studied. Moreover, the studies were often done at the miniplot level, the results of which cannot be linearly scaled up to the watershed.

The results can be portrayed per land-use system, per agroecological zone, per country, and also per nutrient for the entire continent. The average $N, P$, and $\mathrm{K}$ balances for Africa were $-22,-2.5$, and $-15 \mathrm{~kg} \mathrm{ha}^{-1} \mathrm{yr}^{-1}$, respectively. Nutrients exported in harvested products, in runoff, and in eroding sediments were high and caused the balances to be negative. The implication of the figure is that on average, soils in Africa must supply $22 \mathrm{~kg} \mathrm{~N} \mathrm{ha}^{-1}$ each year to balance the ledger, leading to a decline of the $\mathrm{N}$ stocks. Figure $2-1$ shows the results averaged for each country. There are countries with near-equilibrium nutrient balances and those with high nutrient depletion.

Nutrient depletion is most intense in East Africa, next in coastal West Africa and southern Africa, and least intensive in the Sahelian Belt and Central Africa (Table 2-2). In East Africa, major faulting and volcanic activity have produced red fertile soils derived from basalt that are generally known as Nitisols (FAO, 1988)-rhodic groups and subgroups of Alfisols and Oxisols (Soil Survey Staff, 1992)-and Vertisols at low landscape positions. High nutrient depletion is due to high outputs of nutrients in harvested products and erosion and also in the relatively high inherent fertility of the soils. Coastal West African countries are dominated by Alfisols of moderate fertility, in both humid forest and moist savanna regions. Southern Africa also is dominated by Alfisols, many of which are sandy and of low inherent fertility. Often associated with these are Vertisols derived from basalt that are intensively cultivated as dambo gardens. The Sahelian belt-from Senegal to Somalia-is characterized by sandy Alfisols and Entisols, often of extremely low fertility, and irrigated Vertisols and Entisols adjacent to major rivers. Central Africa is characterized by infertile, acid Ultisols, Oxisols, and Entisols in both forested and savanna regions. 


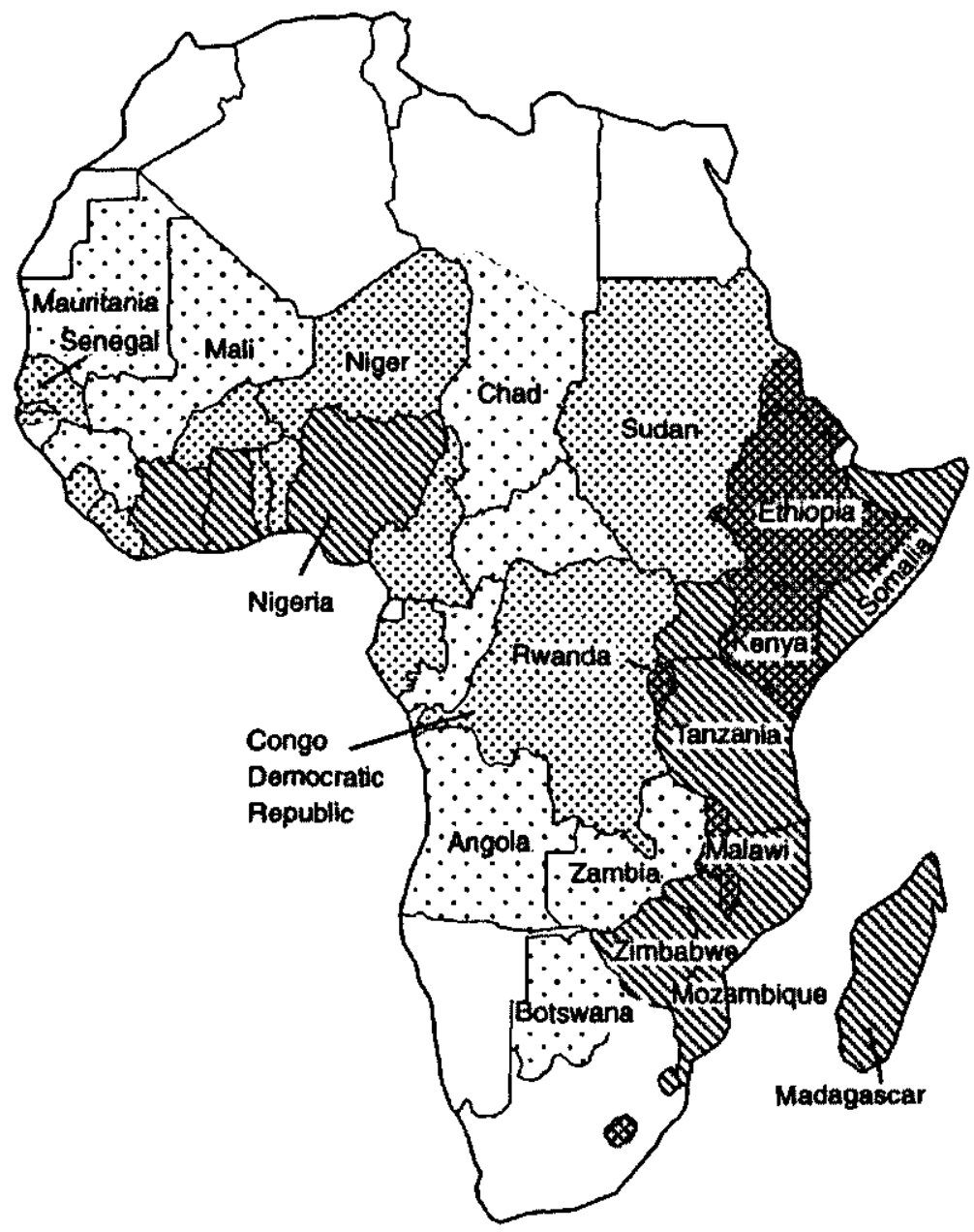

\begin{tabular}{|c|c|c|c|c|}
\hline & & \multicolumn{3}{|c|}{ Nutrient depletion $\left(\mathrm{kg} \mathrm{ha}^{-1} \mathrm{yr}^{-1}\right)$} \\
\hline & & $N$ & $P$ & $K$ \\
\hline$\because \because$ & Low & $<10$ & $<1.7$ & $<8.3$ \\
\hline$\because \because 3$ & Moderate & 10 to 20 & 1.7 to 3.5 & 6.3 to 16.6 \\
\hline ANW & High & 20 to 40 & 3.5 to 6.6 & 16.6 to 33.2 \\
\hline 格 & Very high & $\geqslant 40$ & $\geqslant 6.6$ & $\geqslant 33.2$ \\
\hline
\end{tabular}

Fig. 2-1. Classification of soil nutrient balances for the arable land of sub-Saharan Africa (adapled from Stoorvogel \& Smaling, 1990). 
Table 2-2. Estimated nutrient-depletion rates in cultivated land in subregions of sub-Saharan Africa in 1983, excluding South Africa. $†$

\begin{tabular}{|c|c|c|c|c|c|c|}
\hline \multirow[b]{2}{*}{ Parameter } & \multicolumn{6}{|c|}{ Subregiont } \\
\hline & $\begin{array}{c}\text { East } \\
\text { African } \\
\text { Highlands }\end{array}$ & $\begin{array}{c}\text { Coastal } \\
\text { West } \\
\text { Africa }\end{array}$ & $\begin{array}{l}\text { Southern } \\
\text { Africa }\end{array}$ & $\begin{array}{l}\text { Sahelian } \\
\text { Belt }\end{array}$ & $\begin{array}{l}\text { Central } \\
\text { Africa }\end{array}$ & $\begin{array}{c}\text { Total } \\
\text { sub-Saharan } \\
\text { Africa }\end{array}$ \\
\hline $\begin{array}{l}\text { Cultivated land (million ha) } \\
\text { Depletion rate, }\left(\mathrm{kg} \mathrm{ha}^{-1} \mathrm{yr}^{-1}\right)\end{array}$ & 39 & 63 & 24 & 55 & 20 & 201 \\
\hline $\mathbf{N}$ & 36 & 27 & 20 & 11 & 10 & 22 \\
\hline $\mathbf{P}$ & 5 & 3 & 2 & 2 & 1 & 2.5 \\
\hline $\mathbf{K}$ & 25 & 18 & 14 & 8 & 8 & 15 \\
\hline \multicolumn{7}{|c|}{ Total depletion (million $\mathrm{t} \mathrm{ha}^{-1} \mathrm{yr}^{-1}$ ) } \\
\hline $\mathrm{N}$ & 1.38 & 1.70 & 0.48 & 0.63 & 0.21 & 4.40 \\
\hline $\mathbf{P}$ & 0.19 & 0.19 & 0.06 & 0.09 & 0.02 & 0.55 \\
\hline $\mathbf{K}$ & 0.97 & 1.14 & 0.32 & 0.45 & 0.15 & 3.03 \\
\hline
\end{tabular}

† Source, Stoorvogel and Smaling (1990).

$¥$ Countries included in each region as follows East African Highlands: Burundi, Ethiopia, Kenya, Madagascar, Rwanda, Tanzania, and Uganda. Coastal West Africa: Benin, Cameroon, Côte d'Ivoire, Ghana, Guinea, Liberia, Nigeria, Sierra Leone, and Togo. Southern Africa: Angola, Botswana, Lesotho, Malawi, Mozambique, Swaziland, Zambia, and Zimbabwe. Sahelian Belt: Burkina Faso, Chad, The Gambia, Mali, Mauritania, Niger, Senegal, Somalia, and Sudan. Central Africa: Central African Republic, the two Congos, and Gabon.

\section{Subnational Scale}

The subcontinental scale and uneven data availability implicitly brought about a considerable amount of generalization, simplification, and aggregation. As a follow-up, similar studies were done at subnational scales, i.e., in the 2200$\mathrm{km}^{2}$ subhumid Kisii District in Kenya (Smaling et al., 1993) and in the 12230 $\mathrm{km}^{2}$ semi-arid region of southem Mali (Van der Pol, 1992). Primary data were available on climate, soils, land use, mineral fertilizers, farmyard manure, crop yields and residues and their nutrient content, and to a lesser extent on erosion. Kisii soils are predominantly well drained, very deep, and rich in nutrients (Mollisols, Luvisols), with the exception of $P$. Mean annual rainfall ranges between 1350 and $2050 \mathrm{~mm}$. Major food crops in the district are maize and bean (Phaseolus vulgaris L.), often grown in association. Major cash crops include tea [Camellia sinensis (L.) Kuntze], coffee (Coffea arabica L.), and pyrethrum [Chrysanthemum cinerariaefolium (Trev.) Bocc.]. Most farm holdings in addition comprise small improved pastures for livestock. Less than $5 \%$ of the land is left fallow during a year. In southern Mali, millet [Pennisetum glaucum (L.) R. Br.; $20 \%$ of arable land], sorghum [Sorghum bicolor (L.) Moench; $17 \%$ of arable land], and cotton (Gossypium hirsutum L.; $15 \%$ of arable land) are the major crops of the region. Smaller percentages of maize and groundnut (Arachis hypogaea L.) are grown. Approximately $29 \%$ of the arable land is left fallow in a year.

Calculations revealed that annual nutrient depletion in Kisii District was $112 \mathrm{~kg} \mathrm{~N} \mathrm{ha}^{-1}, 2.5 \mathrm{~kg} \mathrm{P} \mathrm{ha}^{-1}$, and $70 \mathrm{~kg} \mathrm{Kha}^{-1}$ (Table 2-3), whereas in southern Mali the values were $25 \mathrm{~kg} \mathrm{~N} \mathrm{ha}^{-1}, 0 \mathrm{~kg} \mathrm{P} \mathrm{ha}^{-1}$, and $20 \mathrm{~kg} \mathrm{~K} \mathrm{ha}^{-1}$ (Table 2-4). In 
Table 2-3. Nutrient budget in Kisii District, Kenya. $†$

\begin{tabular}{|c|c|c|c|c|c|c|c|c|c|c|}
\hline Element & IN 1 & IN 2 & IN 3 & IN 4 & OUT I & OUT 2 & OUT 3 & OUT 4 & OUT 5 & Total \\
\hline & & & . & . & $\ldots$ & $\mathrm{gha}^{-1} \mathrm{yr}$ & & & & - \\
\hline $\mathbf{N}$ & 17 & 24 & 6 & 8 & 55 & 6 & 41 & 28 & 37 & -112 \\
\hline$\ddot{p}$ & 12 & 5 & 1 & & 10 & 1 & 0 & & 10 & -3 \\
\hline K & 2 & 25 & 4 & & 43 & 13 & 9 & & 36 & -70 \\
\hline
\end{tabular}

† Source, Smaling et al. (1993).

Table 2-4. Nutrient budget in southern Mali. ${ }^{\prime}$

\begin{tabular}{|c|c|c|c|c|c|c|c|c|c|}
\hline Element & IN 1 & IN 2 & IN 3 & IN 4 & OUT $1+2$ & OUT 3 & OUT 4 & OUT 5 & Total \\
\hline & & & & & & & & & \\
\hline $\mathrm{N}$ & 7 & 3 & 10 & 3 & 23 & 4 & 12 & 9 & -25 \\
\hline $\mathbf{p}$ & 2 & 1 & 2 & & 3 & 0 & & 2 & 0 \\
\hline K & 2 & 3 & 6 & & 14 & 4 & & 13 & -20 \\
\hline
\end{tabular}

$\uparrow$ Source, Van der Pol (1992).

Kisii, removal of nutrients in the harvested product (OUT 1) was the strongest contributor to the negative balance, followed by runoff and erosion and, for $\mathrm{N}$, leaching. Use of mineral fertilizers and manure in Mali is much less than in Kenya, but crop production is also lower, reflected in lower values of the output of aboveground crop parts (OUT 1). Because of lower rainfall and flatter topography, losses from leaching, denitrification, and erosion also were smaller in Mali.

At the crop level, conclusions drawn from the Kisii study revealed that pyrethrum is the big nutrient miner $\left(-147 \mathrm{~kg} \mathrm{~N},-24 \mathrm{~kg} \mathrm{P},-96 \mathrm{~kg} \mathrm{~K} \mathrm{ha}^{-1} \mathrm{yr}^{-1}\right)$, whereas tea has the most favorable nutrient balance $(-67 \mathrm{~kg} \mathrm{~N},+6 \mathrm{~kg} \mathrm{P},-30 \mathrm{~kg}$ $\left.\mathrm{K} \mathrm{ha}^{-1} \mathrm{yr}^{-1}\right)$. Pyrethrum receives little mineral or organic fertilizer, has a high nutrient content per unit of harvested product and protects the surface poorly against erosion. Tea, however, receives substantial amounts of mineral fertilizer and offers good protection to the topsoil. In southem Mali, millet is the big nutrient miner $\left(-47 \mathrm{~kg} \mathrm{~N},-3 \mathrm{~kg} \mathrm{P},-37 \mathrm{~kg} \mathrm{~K} \mathrm{ha}^{-1} \mathrm{yr}^{-1}\right)$, whereas cotton has the most favorable nutrient balance $\left(-21 \mathrm{~kg} \mathrm{~N},+7 \mathrm{~kg} \mathrm{P},-9 \mathrm{~kg} \mathrm{~K} \mathrm{ha}^{-1} \mathrm{yr}^{-1}\right)$. Millet receives virtually no mineral or organic fertilizer and has a high nutrient content per unit of harvested product as compared with sorghum. Cotton, however, receives substantial amounts of fertilizer.

\section{Farm and Field Scale}

The subcontinental and subnational studies revealed that $N$ and $P$, on average, are moderately to strongly mined. In Kisii District, soils are still rich enough to produce high agricultural output. But for how long? And how will farmers be told not to go for high crop yields when they can obtain them? Should farmers 
apply $\mathrm{N}$ fertilizer when the $\mathrm{N}$ balance is as negative as $-112 \mathrm{~kg} \mathrm{ha}^{-1}$ ? These questions were posed by many interested parties after publication of the subcontinental and subnational studies, and they triggered the development of a proposal for a nutrient monitoring programme (NUTMON) at the farm scale (Smaling \& Fresco, 1993; Smaling et al., 1996).

In 1995, a Rockefeller Foundation-sponsored NUTMON pilot project started in 26 farms in three agroecologically and ethnically different districts in Kenya (Kisii, Kakamega, and Embu). The initial phase included interpretation of satellite images and identification of more or less homogenous land-use zones. In each zone, rural appraisals were then held, which led to the identification of characteristic farm types for each land-use zone and the subsequent selection of pilot farms. For each farm, an initial inventory was done on household composition, farm and field architecture, agricultural activities, and nutrient stocks. This was then followed by monthly monitoring of farm management activities related to nutrient flows and related economic factors (De Jager et al., 1998b).

Results so far indicate an average negative $\mathrm{N}$ balance of $-71 \mathrm{~kg} \mathrm{ha}^{-1}$ for the three districts (Van den Bosch et al., 1998); however, if one just looks at the flows that are managed directly by the farmer (mineral and organic fertilizers, and harvested crops and residues leaving the farm), the annual $\mathrm{N}$ balances are positive $\left(10,35\right.$, and $46 \mathrm{~kg} \mathrm{~N} \mathrm{ha}^{-1}$ for Kisii, Kakamega, and Embu Districts, respectively). Phosphorus and $K$ balances were close to equilibrium. It appeared that input through manure derived from communal lands, where animals are grazing during daytime, is an important nutrient input at the farm level. The virtual absence of these communal lands in Kisii explains the lower $\mathrm{N}$ balance value. One major methodological constraint was that some flows were actually measured, whereas others such as leaching and gaseous losses were estimated. Yet they influence the value of the balance very much.

Relations also have been established between economic performance indicators, the socioeconomic environment, farm management practices, and nutrient balances. It was found that net farm income shows no relation to the nutrient balance (De Jager et al., 1998a). A high degree of market orientation, however, correlated well and negatively with the $\mathrm{N}$ and $\mathrm{K}$ balance. The market-oriented farms located in the densely populated areas and characterized by intensive crop and livestock activities import nutrients through fertilizers and animal feeds, but the amount is insufficient to compensate for the outflow through marketed products, leaching, and erosion. Subsistence farms in the less populated areas (drier parts of Kakamega and Embu) have a relatively successful strategy to concentrate nutrients through grazing of cattle in communal lands. Off-farm income also proved very important for households to survive. Without this source of income, $54 \%$ of the farms in the sample would be below what the World Bank considers to be the poverty line. The replacement costs of mined nutrients amounted up to $35 \%$ of the average net farm income.

At the crop and field level, cash crops such as tea and coffee realized higher gross margins and considerably lower nutrient mining levels than the major food crops, maize, and beans. Application of sufficient nutrients to food crops apparently is not viable in the current economic environment (De Jager et al., 1998a). 


\section{DIFFERENT SCALES: DIFFERENT CONCLUSIONS}

\section{Comparing Subcontinental and Subnational Scales}

The Kisii District study yielded nutrient loss values of $-112 \mathrm{~kg} \mathrm{~N}$ and -3 $\mathrm{kg} \mathrm{P} \mathrm{ha}^{-1} \mathrm{yr}^{-1}$. In the subcontinental study, the extrapolated nutrient balance for Kisii District would have been $-75 \mathrm{~kg} \mathrm{~N}$ and $-5 \mathrm{~kg} \mathrm{P} \mathrm{ha}^{-1} \mathrm{yr}-1$. In the latter study, all soils would have been in Fertility Class 2 (moderate), characterized by $1 \mathrm{~g} \mathrm{~N} \mathrm{~kg}^{-1}$ soil and $0.2 \mathrm{~g} \mathrm{P} \mathrm{kg}^{-1}$ soil. In reality, however, the soils have a higher $\mathrm{N}$ content, which could be adequately covered in the district study. Pyrethrum turned out to be the major nutrient miner in the district study, but it was not included in the supranational study because it lacked importance at that scale. Hence, the differences between the results of the two studies are differences in resolution.

\section{Comparing Subnational and Farm Scales}

In the NUTMON pilot, farm-determined nutrient balances for Kisii were $-102 \mathrm{~kg} \mathrm{~N},-2 \mathrm{~kg} \mathrm{P}$, and $-34 \mathrm{~kg} \mathrm{~K} \mathrm{ha}^{-1} \mathrm{yr}^{-1}$, which compare well with the subnational estimates (Van den Bosch et al., 1998). Variation around the mean, however, was considerable. Nutrient stocks used in the subnational study were average values for land units on a 1:100 000-scale soil map for Kisii District (Smaling et al., 1993). The six farms in Kisii District had total $\mathrm{N}$ concentration between 1.5 and $4.6 \mathrm{~g} \mathrm{~kg}^{-1}$ soil and total $P$ concentration of 0.9 to $1.3 \mathrm{~g} \mathrm{~kg}^{-1}$ soil.

\section{Comparing Farm and Enterprise Scales}

Nutrient stocks of individual plots within farms and village territories can differ considerably. Reasons range from differences in soil texture, land-use and fallow history to microclimatic differences. Smallholder farmers exploit microvariability, because for each weather condition, there are pieces of land where crops perform well (Brouwer et al., 1993). Hence, farm and field heterogeneity is often regarded as an asset by those who are resource poor and risk averse, their goal being food security rather than bumper harvests. An example of taking advantage of heterogeneity is the use of termite mounds, representing spots of relatively high fertility. Another striking example of farm-level variation is in the ring management systems in semiarid West Africa, where inner circles near the farms and village are much more intensively used and managed than outer rings (Prudencio, 1993; Sédogo, 1993). Of the three subsystems shown in Table 2-5, the homestead fields represent the plots just around the homestead, and receive substantial amounts of nutrients from animal manure and household waste. As a consequence, soil productivity in this part of the farm remains at a relatively high level.

In the NUTMON pilot project, it became clear that cash crop and food crop plots are treated quite differently as regards nutrient flows (De Jager et al., 1998b). The role of livestock in the farming system and the amount of manure reaching certain plots largely determines within-farm differences in nutrient stocks and flows (Mohamed-Saleem, 1998; Van den Bosch et al., 1998). 
Table 2-5. Nutrient stocks of different subsystems in a typical upland farm in the Sudan-savanna zone of West Africa.

\begin{tabular}{lccccc}
\hline Farm subsystem & $\mathrm{pH}$ in $\mathrm{H}_{2} \mathrm{O}$ & Organic $\mathrm{C}$ & Total $\mathrm{N}$ & Extractable $\mathrm{P}$ & Exchangeable $\mathrm{K}$ \\
\hline & & - & $\mathrm{g} \mathrm{kg}^{-1}$ & $\mathrm{mg} \mathrm{kg}^{-1}$ & mmol $_{\mathrm{c}} \mathrm{kg}^{-1}$ \\
Homestead fields & $6.7-8.3$ & $11-22$ & $0.9-1.8$ & $20-220$ & $4-24$ \\
Village fields & $5.7-7.0$ & $5-10$ & $0.5-0.9$ & $13-16$ & $4-11$ \\
Bush fields & $5.7-6.2$ & $2-5$ & $0.2-0.5$ & $5-16$ & $0.6-1$ \\
\hline
\end{tabular}

$\uparrow$ Source, Sédogo (1993).

\section{NEED FOR INDICATORS AS A MEASURE OF PRODUCTIVITY AND SUSTAINABILITY}

The studies discussed in this chapter contributed to the shortlisting of nutrient balance as a land-quality indicator in a World Bank initiative to capture the current quality of land, the pressures exerted on it, and societal responses (Pieri et al., 1995). Does nutrient balance qualify as such? Perhaps, but it may be wise to first list the many constraints that may preclude its usefulness and the opportunities involved.

\section{Constraints}

Farmers continue to deplete soil nutrients as long as the land provides them sufficient food and cash to make it through the year. In Kisii District, for example, gross nutrient mining was observed, but as soil fertility is still rather high, crop production was also rather high. In other words, as long as the soil is able to buffer the negative balances before reaching low levels of nutrient availability, farmers will not notice changing soil fertility the next year. The nutrient balance alone is therefore not sufficient as an indicator of soil productivity. It needs to be linked with soil nutrient stocks, either with the total stock or with the stock of available nutrients. The latter may be defined as the nutrients that are present in the soil solution at the beginning of the growing season or will enter the soil solution during the season.

Not all inputs and outputs are easily measured. Determining inputs by mineral fertilizers may require a quick look at district statistics, and yield estimates may just require some ground-truth measurements. For leaching and gaseous losses, however, transfer functions are needed, which are made up of different parameters with values that are often obtained from secondary sources, and hence their values are less reliable than those of nutrients in crop products.

A nutrient balance value may contain considerable error because it reflects the aggregation of five inputs and five outputs. The sheer lack of certain categories of primary data in the tropics makes it difficult to put the nutrient balance concept into operation. There are no examples of benchmark sites where all 10 parameters of Table 2-1 have been measured simultaneously over sufficiently long periods.

For the continental, national, and district studies, input data for the nutrient balance are mostly derived from subdistrict statistics and are thus already aggre- 
Table 2-6. Ratios of easy-to-measure nutrient flows with the sums of all flows.

\begin{tabular}{|c|c|c|c|c|c|c|}
\hline \multirow[b]{2}{*}{ Element } & \multicolumn{2}{|c|}{$\begin{array}{c}(\mathrm{IN} 1+\mathrm{IN} 2) \\
\text { (total inputs) }\end{array}$} & \multicolumn{2}{|c|}{$\begin{array}{c}\text { (OUT } 1+\text { OUT 2) } \\
\text { (total outputs) }\end{array}$} & \multicolumn{2}{|c|}{$\begin{array}{c}\text { (Balance } 1+2) \\
\text { (total balance) }\end{array}$} \\
\hline & Kisii & Mali & Kisii & Mali & Kisii & Mali \\
\hline $\begin{array}{l}\mathbf{N} \\
\mathbf{P} \\
\mathrm{K}\end{array}$ & $\begin{array}{l}0.75 \\
0.94 \\
0.87\end{array}$ & $\begin{array}{l}0.43 \\
0.60 \\
0.45\end{array}$ & $\begin{array}{l}0.37 \\
0.52 \\
0.55\end{array}$ & $\begin{array}{l}0.48 \\
0.60 \\
0.45\end{array}$ & $\begin{array}{r}0.18 \\
-2.00 \\
0.41\end{array}$ & $\begin{array}{l}0.52 \\
1.00 \\
0.45\end{array}$ \\
\hline
\end{tabular}

gated to some extent (soil maps, district statistics, national fertilizer-use statistics). Moreover, the loss of resolution and of relevant human-induced and natural spatial variability tends to produce average figures and trends without any information on standard deviation.

\section{Opportunities}

For the nutrient balance to become a meaningful land-quality indicator, it is necessary to develop a quality index, relating nutrient balance to nutrient stocks in one way or another. The concept of stocks and flows is in line with economists' style of budgeting and may help in bridging gaps between disciplines. Moreover, it will be possible to estimate how long nutrient mining in a given land-use system can continue unabated.

The most straightforward approach would be the use of nutrient balance and nutrient stocks where both include all nutrients, irrespective of their availability. The strength of such an index is that it provides information on the longterm fate of the land and not just of the next crop. A disadvantage is that it is not directly related to the nutrients that are immediately available and hence not to crop growth. Another drawback is the difficulty to assess the values of the nutrient balance, certainly in low-data environments. An index consisting only of flows that can be easily determined would have much more practical meaning. These flows are IN 1 and IN 2 (mineral and organic fertilizers), and OUT 1 and OUT 2 (removed biomass in harvest and crop residues). The values of these four flows are all strongly human influenced and directly reflect the farm households' allocation of capital and labor as well as income generation and food security strategies.

Disadvantages are that potentially important flows are ignored. This would not matter if the proportions of the various INs and OUTs were little affected by the type of agrosystem. It is obvious from Table $2-6$ that neither IN $1+$ IN 2 nor OUT 1 + OUT 2 is a constant portion of the total input or output. Dividing the truncated balance by the total balance (last two columns of Table 2-6) may even lead to negative values (e.g., $P$ in Kisii). Similar results as in Table 2-6 were found for the data by Stoorvogel and Smaling (1990), implying that the use of only INs 1 and 2, and OUTs 1 and 2 instead of all INs and OUTs does not offer good prospects. Nevertheless, the ratio (IN I + IN 2)/(total inputs) presents interesting information, for it indicates the degree of human involvement in nutrient supply. The ratio (OUT 1 + OUT 2)/(total outputs) indicates which fraction of the outputs can be seen as useful. 
In the quest for a land-quality indicator for nutrients that is also directly related to yield, the appropriate flows of available nutrients must first be identified. This is simple for the outputs: OUTs 1 through 4 refer to available nutrients, while OUT 5 (erosion) also refers to nutrients that are not immediately available because they are present in solid organic and inorganic particles, in addition to available nutrients. For the inputs the situation is more complex. The nutrients of IN $\mathbf{4}$ are plant available. Those of IN $\mathbf{3}$ are directly available as far as wet deposition is concerned (estimated at $50 \%$ ), whereas those in dry deposition (the other $50 \%$ ) are in an unavailable form. Those of IN 5 are not available when just considering sedimentation and not run-on. The nutrients of IN 1 and IN 2 are partly or entirely in an available form. $\mathrm{N}$ and $\mathrm{K}$ in chemical fertilizers and $\mathrm{K}$ in organic fertilizers usually can be considered as available. Water-soluble $\mathrm{P}$ fertilizers and organic fertilizers have about the same fraction of available $P$; it is often set at 0.1 , but it varies between 0.05 and 0.2 depending on soil properties and weather conditions. The availability of $\mathrm{N}$ in organic fertilizers is affected by weather conditions, length of growth season, and type of manure. An often-used default value is 0.4 . With these assumptions, the following formulas were applied to estimate the balance of INs and OUTS of available nutrients:

$$
\begin{aligned}
& \text { for } \mathrm{N}:(\mathrm{IN} 1+0.4 \mathrm{IN} 2+\mathrm{IN} 3+\mathrm{IN} 4)-(\text { OUTs } 1 \text { to } 4) \\
& \text { for } \mathrm{P}:(0.1 \mathrm{IN} 1+0.1 \mathrm{IN} 2+0.5 \mathrm{IN} 3)-(\text { OUTs } 1 \text { to } 3) \\
& \text { for } \mathrm{K}:(\mathrm{IN} 1+\mathrm{IN} 2+0.5 \mathrm{IN} 3)-(\text { OUTs } 1 \text { to } 3) \text {. }
\end{aligned}
$$

The thus estimated values were compared with total nutrient stocks in the soils of Kisii and southem Mali. The resulting values for N, P, and $\mathrm{K}$ indicated annual losses of the nutrient stocks in the order of magnitude of $1.2 \%$ for $\mathrm{N}$ and $0.35 \%$ for both $\mathrm{P}$ and $\mathrm{K}$. These values, however, are very strongly affected by the assumptions made in the calculations of the INs and OUTS.

\section{CONCLUSIONS}

The nutrient balance results obtained for the subcontinental study paint a rather gloomy picture. Soil fertility is really at stake; however, it is risky to draw conclusions from low-resolution, aggregated studies. Generally, the largest unit for which soil nutrient balances can be quantified is the field, whereas larger spatial scales can only be dealt with through generalization and aggregations (Stoorvogel \& Smaling, 1997). For nutrient balances, aggregation is a very delicate issue, as the balance itself is made up of at least 10 parameters (Table 2-1), which are in some cases outcomes of regression analysis on again more basic parameters. Also, a negative balance does not necessarily mean that crop production declines instantly because soils may have a large buffering stock of nutrients, sufficient to keep production going for many years (Smaling et al., 1996).

Based on this, we suggest that the subcontinental results should be treated as general awareness raisers, i.e., that soil fertility decline in Africa is a threat and needs attention, just like nutrient accumulation in some parts of Europe needs attention. At the national and subnational levels, results are meant to alert national and subnational policy makers and other stakeholders. Research and develop- 
ment efforts can be better targeted, but again the results do not reveal much on differences in farmers' management and strategies. This becomes visible only during farm-level monitoring activities, as carried out during the NUTMON pilot (Van den Bosch et al., 1998). Similar work is going on in several African countries, such as Kenya (Shepherd \& Soule, 1998), Mali (Defoer et al., 1998), Ethiopia (Elias et al., 1998), and Tanzania (Baijukya \& De Steenhuijsen Piters, 1998). In the recent past, different authors (e.g., Prudencio, 1993; Brouwer et al., 1993; Carter \& Murwira, 1995; De Steenhuijsen Piters, 1995) have shown how risk-averse farmers in West and southern Africa cherish and exploit spatial variation in soil fertility. Analogies in the field of soil and water conservation also are plentiful (Tiffen et al., 1994; Rey et al., 1996), and clearly signal a warning to those who tend to rely only on averages and smoothness of trends. Survival strategies of African farmers are apparently underestimated (Scoones \& Toulmin, 1998).

When considering the suitability of the nutrient balance as a land-quality indicator for nutrients, no index can be put forward as most obvious. Among the possible indices, the ratio of nutrient balance to nutrient stocks may be considered as the best one, but it is not easy to determine. The rather easy to determine ratio (IN $1+$ IN 2)/(total inputs) and the more difficult (OUT $1+$ OUT 2)/(total outputs) have been worked out to some extent in this chapter but do not seem too promising. The observed difficulties make it worthwhile to look further for other approaches. Theoretically there are opportunities in chemical soil analysis. The number of required data, the variability that is to be expected, and the high costs make such alternatives not very attractive.

Can we still say that soil fertility is at stake in Africa? Yes, because apart from the results of the studies presented above, there are a number of on-station and on-farm medium- and long-term trials that quantitatively support that statement. Figure 2-2 shows declining soil fertility in a long-term trial in central Kenya, and Table 2-7 summarizes changes in soil nutrients observed during the

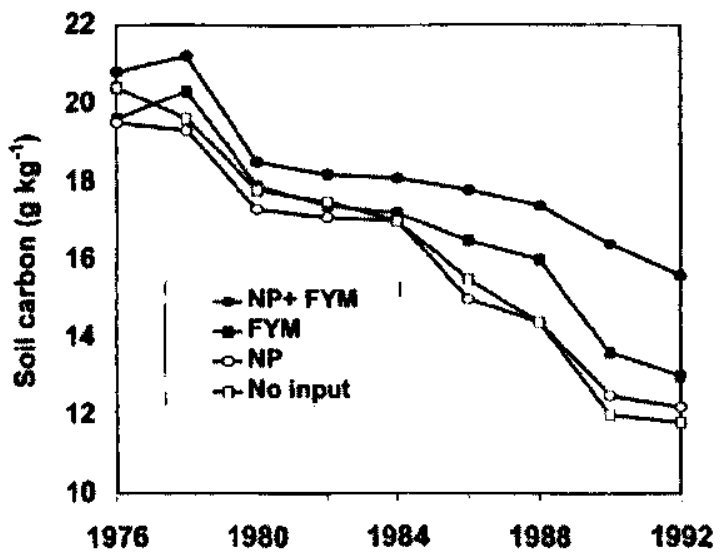

Fig. 2-2. Effect of applications of farmyard manure (FYM, $\left.10 \mathrm{tha}^{-1} \mathrm{yr}^{-1}\right)$, mineral fertilizer (N-P, $120 \mathrm{~kg} \mathrm{~N} \mathrm{ha}^{-1} \mathrm{yr}^{-1}$ and $\left.52 \mathrm{~kg} \mathrm{Pha}^{-1} \mathrm{yr}^{-1}\right)$, and FYM $\left(10 \mathrm{t} \mathrm{ha}^{-1} \mathrm{yr}^{-1}\right)+\mathrm{N}-\mathrm{P}$ fertilizer $\left(120 \mathrm{~kg} \mathrm{~N} \mathrm{ha}^{-1}\right.$ $\mathrm{yr}^{-1}$ and $52 \mathrm{~kg} \mathrm{P}^{\mathrm{Pa}} \mathrm{ha}^{-1} \mathrm{yr}^{-1}$ ) on soil organic $\mathrm{C}$ at 0 t-o $25-\mathrm{cm}$ depth at Kabete, Kenya (S.M. Nandwa, 1997, unpublished data). 
Table 2-7. Changes in soil properties in the top $20-\mathrm{cm}$ layer in nonfertilized, continuously cropped Kenyan soils. $\dagger$

\begin{tabular}{|c|c|c|c|c|c|c|c|c|}
\hline \multirow[b]{2}{*}{ Site } & \multicolumn{2}{|c|}{ Organic C } & \multicolumn{2}{|c|}{ Mehlich P } & \multicolumn{2}{|c|}{ Exchangeable K } & \multicolumn{2}{|c|}{$\mathrm{pH}$ in $\mathrm{H}_{2} \mathrm{O}$} \\
\hline & TI & T2 & $\mathrm{Tl}$ & $\mathbf{T} 2$ & T! & $\mathrm{T} 2$ & T1 & $\mathrm{T} 2$ \\
\hline & \multicolumn{2}{|c|}{$-\mathrm{g} \mathrm{kg}^{-1}-$} & \multicolumn{2}{|c|}{$-\mathrm{mg} \mathrm{kg}^{-1}-$} & \multicolumn{2}{|c|}{$\mathrm{mmol}_{\mathrm{c}} \mathbf{k g}^{-1}$} & & \\
\hline Alfisol (clayey) & 30.7 & 29.9 & 25.8 & 25.2 & 7.2 & 8.1 & 5.1 & 4.9 \\
\hline Alfisol (sandy) $\S$ & 6.8 & 4.8 & 30.6 & 24.7 & 2.7 & 3.5 & 7.0 & 6.9 \\
\hline Oxisolf & 20.5 & 20.1 & 17.2 & 13.4 & 2.0 & 1.7 & 5.1 & 4.7 \\
\hline Psamment\# & 7.9 & 6.7 & 27.0 & 25.1 & 4.9 & 2.9 & 7.7 & 7.0 \\
\hline Ultisol (clayey) $\ddagger$ & 26.2 & 24.9 & 27.7 & 24.5 & 18.7 & 13.0 & 5.8 & 5.8 \\
\hline Ultisol (clayey) $\ddagger$ & 15.7 & 15.8 & 14.8 & 13.2 & 4.6 & 4.0 & 5.4 & 5.3 \\
\hline Ultisol (loamy) & 13.0 & 12.1 & 12.9 & 14.7 & 6.8 & 5.1 & 5.6 & 5.3 \\
\hline Ultisol (sandy)†† & 4.9 & 3.9 & 5.8 & 5.5 & 1.6 & 1.4 & 6.3 & 5.8 \\
\hline
\end{tabular}

$\dagger$ Source, Smaling and Braun (1996).

$\ddagger \mathrm{T} 1=1988, \mathrm{~T} 2=1991$.

$\S \mathrm{T} 1=1988, \mathrm{~T} 2=1990$.

I $\mathrm{T} 1=1988, \mathrm{~T} 2=1992$.

$\# \mathrm{Tl}=1987, \mathrm{~T} 2=1990$.

t† $T I=1987, T 2=1991$.

Fertilizer Use Recommendation Project in different parts of Kenya (Smaling \& Braun, 1996). But is soil fertility at stake all over Africa? No, certainly not! The average nutrient balance may be negative, but thousands of farms will be able to show sustainable nutrient management strategies at satisfactory production levels. And if researchers, farmers, and other stakeholders in the agricultural sector are ready to learn, listen, and subsequently teach, we may be on our way to a better future for agriculture in Africa.

\section{REFERENCES}

Baijukya, F.P., and B. De Steenhuijsen Piters. 1998. Nutrient balances and their consequences in the anana-based land use systems of Bukoba District, northwest Tanzania. In E.M.A. Smaling (ed.) Nutrient flows and balances as indicators of productivity and sustainability in subSaharan African agro-ecosystems. Agric. Ecosyst. Environ. (in press).

Bouma, J., and H.A.J. Van Lanen. 1987. Transfer functions and threshold values: From soil characteristics to land qualities. p. 106-110. In K.J. Beek et al. (ed.) Quantified land evaluation procedures. ITC Publ. 6. Int. Inst. for Aerospace Surv. and Earth Sci., Enschede, the Netherlands.

Brouwer, J., L.K. Fussell, and L. Herrmann. 1993. Soil and crop growth micro-variability in the West African semi-arid tropics: A possible risk-reducing factor for subsistence farmers. Agric. Ecosyst. Environ. 45:229-238.

Carter, S.E., and H.K. Murwira. 1995. Spatial variability in soil fertility management and crop response in Mutoko Communal Area, Zimbabwe. Ambio 24:77-84.

Defoer, T.. H. de Groote, T. Hilhorst, S. Kanté, and A. Budelman. 1998. Participatory action reseanch and quantitative analysis for nutrient management in Southem Mali: A fruitful marriage? In E.M.A. Smaling (ed.) Nutrient flows and balances as indicators of productivity and sustainability in sub-Saharan African agro-ecosystems. Agric. Ecosyst. Environ. (in press).

De Jager, A., I. Kariuki, F.M. Matiri, M. Odendo, and J.M. Wanyama. 1998a. Monitoring nutrient flows and economic performance in African farming systems (NUTMON). IV. Monitoring of farm economic performance in three districts in Kenya. In E.M.A. Smaling (ed.) Nutrient flows and balances as indicators of productivity and sustainability in sub-Saharan African agro-ecosystems. Agric. Ecosyst. Environ. (in press).

De Jager. A., Nandwa, S.M., and P.F. Okoth. 1998b. Monitoring nutrient flows and economic performance in African farming systems (NUTMON). I. Conceptual framework. In E.M.A. Smaling 
(ed.) Nutrient flows and balances as indicators of productivity and sustainability in subSaharan African agro-ecosystems. Agric. Ecosyst. Environ. (In press).

De Steenhuijsen Piters, C.B. 1995. Diversity of fields and farmers: Explaining yield variations in northem Cameroon. Ph.D. thesis. Wageningen Agric. Univ., Wageningen, the Netherlands.

Elias, E., S. Morse, and D.G.R. Belshaw. 1998. The nitrogen and phosphorus balances of some Kindo Koisha farms in southern Ethiopia. In E.M.A. Smaling (ed.) Nutrient flows and balances as indicators of productivity and sustainability in sub-Sahuran African agro-ecosystems. Agric. Ecosyst. Environ. (in press).

FAO. 1988. Revised legend of the FAO-UNESCO soil map of the world. Food and Agriculture Organization of the United Nations, Rome.

FAO/UNESCO. 1977. FAO-UNESCO soil map of the world, 1: 5000000 . Vol. 6. Africa. United Nations Educ., Scientific and Cultural Organ., Paris.

Mohamed-Saleem, M.A. 1998. Nutrient balance patterns in African livestock systems. In E.M.A. Smaling (ed.) Nutrient flows and balances as indicators of productivity and sustainability in sub-Saharan African agro-ecosystems. Agric. Ecosyst. Environ. (in press).

Pieri, C. 1989. Fertilité des terres de savanes. Ministère de la Coopération et CIRAD-IRAT, Montpellier, France.

Pieri, C., J. Dumanski, A. Hamblin, and A. Young. 1995. Land quality indicators. World Bank Dis. Pap. 315. World Bank, Washington, DC.

Prudencio, C.Y. 1993. Ring management of soils and crops in the West African semi-arid tropics: The case of the mossi farming system in Burkina Faso. Agric. Ecosyst. Environ. 47:237-264.

Rey, C., 1. Scoones, and C. Toulmin. 1996. Sustaining the soil. Indigenous soil and water conservation in Africa. Earthscan Publ., London.

Scoones, I., and C. Toulmin. 1998. Soil nutrient balances: What use for policy? In E.M.A. Smaling (ed.) Nutrient flows and balances as indicators of productivity and sustainability in subSaharan African agro-ecosystems. Agric. Ecosyst. Environ. (in press).

Sédogo, P.M. 1993. Evolution des sols ferrugineux lessivés sous culture: Incidence des modes de gestion sur la fertilité. Ph.D. thesis. Univ. of Abidjan, Cote d'Ivoire.

Shepherd, K.D., and M.J. Soule. 1998. Soil fertility management in West Kenya: Dynamic simulation of productivity, profitability and sustainability at different resource endowment levels. In E.M.A. Smaling (ed.) Nutrient flows and balances as indicators of productivity and sustainability in sub-Saharan African agro-ecosystems. Agric. Fcosyst. Environ. (in press).

Smaling, E.M.A., and A.R. Braun. 1996. Soil fertility research in sub-Saharan Africa: New dimensions, new challenges. Commun. Soil Sci. Plant Anal. 27:365-386.

Smaling, E.M.A., and L.O. Fresco. 1993. A decision-support model for monitoring nutrient balances under agricultural land use (NUTMON). Geoderma 60:235-256.

Smaling, E.M.A., L.O. Fresco, and A. de Jager. 1996. Classifying, monitoring and improving soil nutrient stocks and flows in African agriculture. Ambio 25:492-496.

Smaling, E.M.A., J.J. Stoorvogel, and P.N. Windmeijer. 1993. Calculating soil nutrient balances in Africa at different scales: II. District scale. Fert. Res. 35:237-250.

Soil Survey Staff. 1992. Keys to soil taxonomy. 5th ed. Soil Manage. Support Serv. Tech. Monogr. 19. Pocahontas Press, Blacksburg, VA.

Stoorvogel, J.J., and E.M.A. Smaling. 1990. Assessment of soil nutrient depletion in sub-Saharan Africa, 1983-2000. Rep. 28. DLO Winand Staring Ctr. for Integrated Land, Soil and Water Res., Wageningen, the Netherlands.

Stoorvogel, J.J., and E.M.A. Smaling. 1997. Research on soil fertility decline in tropical environments: Integration of spatial scales. Nutr. Cycling Agro-Ecosyst. (in press).

Stoorvogel, J.J., E.M.A. Smaling, and B.H. Janssen. 1993. Calculating soil nutrient balances at different scales: I. Supra-national scale. Fert. Res. 35:227-235.

Tiffen, M., M. Mortimore, and F. Gichuki. 1994. More people, less erosion. Environmental recovery in Kenya. John Wiley \& Sons, New York.

Van den Bosch, H., S. Maobe, V.N. Ogaro, J.N. Gitari, and J. Vlaming. 1998. Monitoring nutrient flows and economic performance in African farming systems (NUTMON): III. Monitoring of nutrient flows in three districts in Kenya. In E.M.A. Smaling (ed.) Nutrient flows and balances as indicators of productivity and sustainability in sub-Saharan African agro-ecosystems. Agric. Ecosyst. Environ. (in press).

Van der Pol, F. 1992. Soil mining: An unseen contributor to farm income in southem Mali. Bull. 325. Royal Tropical Inst., Amsterdam, the Netherlands.

Wagenet, R.J., J. Bouma, and R.B. Grossman. 1991. Minimum data sets for use of soil survey information in soil interpretive models. p. 161-182. In M.J. Mausbach and L.P. Wilding (ed.) Spatial variabilities of soils and landforms. SSSA Spec. Publ. 28. SSSA, Madison, WI. 